\title{
Niepewność jako orientacja etnograficzna
}

Wybuch pandemii COVID-19 okazał się ogromnym zaskoczeniem dla zdecydowanej większości społeczeństw na całym świecie. W różnych częściach globu niemal symultanicznie zaczęły więc dominować silne nastroje niepewności, w ramach których pytanie „co się dzieje?” stawiano naprzemiennie z pytaniem „co nas czeka?". Kontekst dynamicznie postępującej pandemii nie tylko ukazał istniejące problemy systemów opieki zdrowotnej, ale również uruchomił narastające obawy związane z nadchodzącym globalnym kryzysem ekonomicznym. Trudno jest oczywiście przewidywać, w jaki sposób pandemia rzeczywiście wpłynie na światową ekonomię polityczną, niemniej same już nastroje niepewności zorientowane na katastroficzne scenariusze nadchodzącej przyszłości stanowią interesujące źródło antropologicznych problematyzacji.

Niepewność sytuacji pandemicznej i widmo kryzysu stały się wręcz nieodłącznymi elementami życia społecznego, a rozmaite spekulacje, projektowanie i planowanie w znacznej mierze zaczęły wpływać na doświadczenia i praktyki codzienności. Liczby i statystki dotyczące zarażeń koronawirusem zdominowały przekazy medialne, wzmacniając jednocześnie poczucie zagrożenia. Informacje na temat tego, „ile” i „gdzie”, porównywane były w skali globalnej i zestawiane z eksperckimi prognozami. Statystyka, wykresy stały się głównymi narzędziami polityki rekomendacji i planowania. Z perspektywy antropologicznej jednak pandemia COVID-19 ukazała również interesujący kontekst badawczy, w którym radykalnemu przeobrażeniu uległy „umiejscowione temporalności” nadające specyficzny rytm danym lokalnościom (Bryant i Knight 2019). Tym samym społeczne doświadczanie czasu stało się zdecydowanie bardziej dynamiczne, relacyjne i nieustannie aktualizowane, a przeżywana teraźniejszość w coraz większym stopniu zastępowana była możliwymi narracjami kryzysowymi zorientowanymi na przyszłość. W czasie pandemii bowiem wyobrażenia i działania społeczne, jeszcze silniej niż zazwyczaj, przybierają postać "globalnych asamblaży” (Ong 
i Collier 2005), a ich formy oparte są na niepewnych przyszłościach. Interesujące więc wydaje się spojrzenie na pandemię COVID-19 przez pryzmat wyłaniających się w jej ramach kryzysowych niepewności i temporalnych rekonfiguracji. Tego rodzaju perspektywa nie tylko pozwoli na prześledzenie potencjalnego wpływu pandemii na życie społeczne, ale także umożliwi problematyzację klasycznej polityki temporalności w samej antropologii.

\section{Kryzys i niepewność}

Każdy kryzys pociąga za sobą nastroje niepewności, które uruchamiają wyobraźnię społeczną i wpływają na praktyki codzienności. Doświadczanie sytuacji kryzysowych zawsze związane jest bowiem z gwałtownym zerwaniem ciągłości zdarzeń, działań i linearnego rozumienia czasu. Zaburzeniu ulega więc teleologia codzienności, w ramach której familiarna do tej pory teraźniejszość ustępuje miejsca wyobrażeniom o nadchodzących przyszłościach (Bryant i Knight 2019; Pawlak 2019). W konsekwencji przeżywane „tu i teraz” pozbawione jest logiki temporalności, a wszelkie zdarzenia stają się niepewne i trudne do zrozumienia. Przyszłość wyłania się w teraźniejszości i, razem z selektywnymi doświadczeniami z przeszłości, zaczyna nadawać kształt społecznym działaniom, wyobrażeniom i strategiom racjonalizacji.

Pierwsze miesiące globalnej pandemii, podczas których większość krajów wprowadziła tzw. lockdown, uniemożliwiający obywatelom swobodne poruszanie się i ograniczający praktyki codzienności (praca, szkoła, rozrywka), były właśnie przykładem rekonfigurowania oczywistych do tej pory teraźniejszości. Izolacja jednoznacznie uzmysłowiła wielu osobom, że czas i przestrzeń odgrywają znaczące role w zrutynizowanych praktykach społecznych, a ich przeobrażenia mogą zaburzyć doświadczenia codzienności. Tym sposobem podczas lockdownu kategorie „wczoraj”, „dziś” i ,jutro” zaczęły zlewać się w jedną temporalność. Było to szczególnie silnie doświadczane przez pracowniczki i pracowników medycznych, często zmuszonych do „zamieszkania” w miejscu swojej pracy. Płynność temporalnych granic została także ucieleśniona w problemach związanych z pracą zdalną. Podczas gdy dla wielu próba połączenia domu i pracy była niezwykle uciążliwa i kłopotliwa, dla osób uprzywilejowanych praca zdalna stanowiła okazję do ironizowania na temat „dojazdów” z sypialni do pokoju, żartobliwego narzekania na brak fryzjera czy też zoomingu w „białej koszuli”, ale „bez spodni”. Niemniej dla zdecydowanej większości izolacja społeczna oznaczała czas ekonomicznej niepewności i narastających obaw związanych z utratą pracy i brakiem podstawowych środków do życia. Wszystko to miało swe przełożenie na wyłaniające się formy i wyobrażenia najbliższej przyszłości, które coraz częściej rysowane były w czarnych barwach. Niepewność zaczęła więc dominować bieżące narracje społeczne i afektywnie „ładować atmosferę” codzienności (Stewart 2011). W rezulta- 
cie wszystkie nowe informacje o zarażeniach koronawirusem odczytywane były jako alarmujące, a ich interpretacje zwiastowały ponure scenariusze kryzysowej przyszłości.

Niepewność jest ucieleśnieniem doświadczeń sytuacji kryzysowej. Z perspektywy antropologicznej jest więc ona niezwykle interesująca poznawczo, ponieważ wskazuje na istniejące zależności pomiędzy indywidualnymi wyobrażeniami i praktykami społecznymi a szerszymi kontekstami powiązań współczesnego świata (Samimian-Darash i Rabinow 2015). Niepewność ma charakter „możliwy” lub „potencjalny” (Samimian-Darash 2016) i wyłania się w sytuacjach, w których dostępna wiedza jest ograniczona, fragmentaryczna lub trudna do ustalenia. W sytuacjach kryzysowych niepewność zawsze jest zorientowana na przyszłość, aczkolwiek samo napięcie pomiędzy tym, co „możliwe”, a tym, co „potencjalne”, zakłada różne rozumienie relacji pomiędzy przeszłością, teraźniejszością a przyszłością (Samimian-Darash 2016). Zatem podczas gdy niepewność „potencjalna" jest ciągłym pytaniem o nieustannie zmieniające się bieżące warunki życia społecznego, niepewność „możliwa” uruchamia doświadczenia z przeszłości, aby wypełnić temporalną lukę kryzysowej teleologii codzienności i odpowiedzieć na pytanie: „co się stanie” w najbliższej przyszłości (Samimian-Darash 2016). W przypadku pandemii COVID-19 ciągłe operowanie wykresami, spekulacjami i projekcjami spotęgowało nastroje niepewności, w których to, co przeszłe (epidemie SARS i MERS), mieszało się z tym, co aktualne i wyobrażone. W konsekwencji teraźniejszość okazywała się trudna do uchwycenia, a na jej miejsce zaczęły pojawiać się różne wizje przyszłości, w których życie społeczne kształtowane będzie przez „nową normalność”.

Co istotne, niepewność jest stanem afektywnym, aczkolwiek nie ogranicza się ona tylko do indywidualnych przeżyć i odczuć. Będąc ściśle powiązaną z zależnościami społecznymi, ekonomicznymi i politycznymi, niepewność ma charakter "falujący” i łączy to, co prywatne i codzienne, z tym, co publiczne (Ahmed 2004: 117). Niepewność stanowi więc element szerszego kontekstu „afektywnych ekonomii”, w ramach których indywidualne emocje „wynurzają się" w przestrzeniach publicznych i nadają kształt relacjom społecznym (Ahmed 2004). Afektywność przeciągających się nastrojów niepewności - a z takimi mamy zazwyczaj do czynienia w sytuacjach pandemii - problematyzuje też samo zjawisko kryzysu i sposób jego doświadczania. Kryzys przestaje bowiem być zaskakującym zdarzeniem, w którym „porządek” został zastąpiony przez „nieporządek”. Nie jest już wówczas tylko „epizodycznym momentem”, pewnego rodzaju społecznym „zawieszeniem” czy też odejściem od "normalności” (Vigh 2008). Wydłużająca się niepewność sprawia, że kryzys staje się kontekstem codzienności, a jego chroniczność w znaczący sposób wpływa na wyobrażenia i praktyki społeczne. 


\section{Orientacja etnograficzna}

Pandemia COVID-19 pokazuje, że niepewność i temporalne rekonfiguracje kryzysowych doświadczeń codzienności rzucają nieco inne światło na politykę temporalności w antropologii. Zwrócenie uwagi badawczej na niepewność wiąże się bowiem ze zmianą orientacji etnograficznej, a więc kierunków dociekań i problematyzacji antropologicznego "tu i teraz”. Pojęcie orientacji związane jest z doświadczeniami czasu, przestrzeni i materialności, za sprawą których badane światy społeczne nabierają kształtów, znaczeń i praktyk (Ahmed 2010). To dzięki orientacji skupiamy naszą etnograficzną uwagę badawczą na partykularnych kwestiach, obserwujemy i uczestniczymy w terenie. Orientacja w znacznej mierze kształtuje więc proces produkowania wiedzy terenowej, ponieważ dzięki niej możliwe jest etnograficzne materializowanie się istniejących zależności, praktyk, wyobrażeń i relacji społecznych.

W terenie zawsze jesteśmy zorientowaniu na coś. Bez względu na problematykę badań, orientacja terenowa ukierunkowuje nas na podążanie za specyficznymi tropami, zwracanie uwagi na interesujące nas powiązania i problematyzowanie tego, co oczywiste W klasycznej antropologii orientacja etnograficzna ukierunkowana była na pewność której źródeł poszukiwano natomiast w przeszłości, pamięci i transmisji tego, co minione Tego rodzaju perspektywa badawcza wywarła znaczący wpływ na samą politykę temporalności w antropologii, w której to właśnie przeszłość stała się głównym kontekstem poznawczym. W rezultacie antropologia została „skolonizowana” przez „logikę reprodukcji, siłę zwyczajów, dynamikę pamięci, trwanie habitusu, powolny ruch codzienności i podstępną tradycję w życiu społecznym" (Appadurai 2013: 285). Nie chodzi oczywiście o to, że przeszłość nie odgrywa już dziś żadnej roli w antropologicznym przedsięwzięciu, ale raczej o to, że badania współczesnych wyobrażeń i praktyk społecznych powinny brać pod uwagę ich przyszłościowe ukierunkowanie. Życie społeczne wytwarzane jest przecież nie tylko na podstawie tego, co było, ale także tego, co będzie. Aby więc spróbować wyjaśnić, jak działa świat, antropologia musi być zorientowana na wyłaniające się scenariusze przyszłości oraz ich role i funkcje w bieżących procesach społecznych, kulturowych, ekonomicznych i politycznych. Dzięki temu możliwe będzie wypracowanie "nowych powiązań pomiędzy indywidualną wyobraźnią a faktami społecznymi” (Hastrup 2005: 8, 11, 16), za sprawą których manifestuje się złożoność życia społecznego. Kontekst niepewności orientuje etnograficzną uwagę badawczą na tego rodzaju temporalne zależności i uwikłania. Pozwala to na odejście od często statycznie rozumianych „przeszłości w teraźniejszości” w stronę relacyjnych i dynamicznych perspektyw przyszłościowych, które - w kontekście narastających widm kryzysów ekonomicznych, klimatycznych i politycznych - w znaczący sposób wpływają na codzienne życie społeczne (Salazar, Pink, Irving, Sjöberg 2017; por. Heffernan i Pawlak 2020; Pawlak 2019). 
Z perspektywy antropologicznej sytuacja pandemii i widmo nadchodzącego kryzysu ekonomicznego wywołują więc etnograficzny „zawrót głowy”, w którym przeszłość i przyszłość wzajemnie przenikają się w teraźniejszych formach działań i racjonalizacji (Knight 2016). Jest to złożony kontekst globalnych zależności, w którym uwaga badawcza zorientowana na niepewność pozwala problematyzować to, co znane i nieznane możliwe i wyobrażone. Pandemia wytwarza i uaktualnia bowiem różnego rodzaju scenariusze działań, które nieustannie poddawane są negocjacjom i interpretacjom opartym na dynamicznie rozwijającej się sytuacji codzienności. Niepewność pokazuje więc, w jaki sposób przyszłość wyłania się w teraźniejszości, nadając jednocześnie kształt codziennym praktykom społecznym i sposobom radzenia sobie $\mathrm{z}$ tym, co niewiadome. Odkrywa tym samym formy angażowania się ludzi w trudne, bieżące, a często też zaskakujące, doświadczenia oraz ujawnia temporalne rekonfiguracje, w których przeszłość i przyszłość ulegają wyobrażeniowym procesom kojarzenia (Kleist i Jansen 2016; Pawlak 2019). Etnograficzne zorientowanie na niepewność rzuca więc interesujące światło poznawcze na istniejące zależności społeczne, kulturowe, ekonomiczne i polityczne, jak również niuansuje role różnych temporalności w życiu codziennym.

Niepewność jest wielowymiarowa, kontekstualna i uwarunkowana społeczną dialektyką wiedzy i niewiedzy To afektywny stan będący rezultatem napięcia pomiędzy tym, co doświadczane, a tym, co wydaje się możliwe w nadchodzącej przyszłości. Oczywiście antropologia zawsze praktykowana jest tu i teraz, próbując przy tym nadać sens wyobrażeniom, praktykom i relacjom społecznym. We współczesnym świecie coraz częściej jednak zaczynają dominować narracje kryzysowe, w których biznes, polityka, technologia, kultura i natura wzajemnie na siebie oddziałują. Kontekst przygotowań związanych z drugą falą zarażeń koronawirusem, planowanie zabezpieczeń ekonomicznych w nadchodzącym kryzysie czy też projektowanie liczb, wykresów i statystyk to przykłady na to, że przyszłość odgrywa niezwykle istotną rolę w teraźniejszych działaniach i zdarzeniach. Mimo że jest to przyszłość wyobrażona, spekulowana i w rzeczywistości nigdy może nie nadejść, to jednak zawsze jest ona afektywna i domaga się reakcji. Tym samym antropologia nie powinna dziś zatrzymywać się na horyzontach przeszłości, a raczej nieustannie poruszać się pomiędzy przeszłością i przyszłością, eksplorując jednocześnie bieżącą dynamikę procesów, praktyk, relacji i zjawisk. Zadaniem antropologii nie jest więc poznanie tego, „Co” się stanie, a raczej wyjaśnienie, dlaczego, jak i kiedy ludzie uważają, że „coś” się stanie (Pawlak 2019). 


\section{Bibliografia}

Ahmed S.

2004 Affective economies, „Social Text” nr 22 (2), s. 117-139.

2010 Orientations Matter, w: New Materialisms. Ontology, Agency and Politics, D. Coole, S. Frost (red.), Durham-London, s. 234-257.

Appadurai A.

2013 Future as Cultural Fact: Essays on the Global Condition, London.

Bryant R., Knight D.M.

2019 The Anthropology of the Future, New York.

Hastrup K.

2005 Performing the World: Agency, Anticipation and Creativity, „The Cambridge Journal of Anthropology" nr 25 (2), s. 5-19.

Heffernan T., Pawlak M.

2020 Crisis futures: The affects and temporalities of economic collapse in Iceland, „History and Anthropology" nr 31 (3), s. 314-330.

Kleist N., Jansen S.

2016 Introduction: Hope over Time-Crisis, Immobility and Future-Making, „History and Anthropology" nr 27 (4), s. 373-392.

Knight D.M.

2016 Temporal Vertigo and Time Vortices on Greece's Central Plain, „The Cambridge Journal of Anthropology" nr 34 (1), s. 32-44.

Ong A., Collier S.J. (red.)

2005 Global Assemblages. Technology, Politics, and ethics as anthropological problems, Malden.

Pawlak M.

2019 Antycypacja, afektywne ekonomie i temporalność w (post)kryzysowej Islandii, „LUD” nr 103, s. 181-206.

Salazar J.-F., Pink S., Irving A., Sjöberg J. (red.)

2017 Anthropologies and Futures. Researching Emerging and Uncertain Worlds, LondonNew York.

Samimian-Darash L.

2016 Practicing Uncertainty: Scenario-Based Preparedness Exercises in Israel, „Cultural Anthropology" nr 31(3), s. 359-386.

Samimian-Darash L., Rabinow P.

2015 Modes of Uncertainty. Anthropological Cases, Chicago.

Stewart K.

2011 Atmospheric attunements, „Environment and Planning D: Society and Space” nr 29, s. 445-453.

Vigh $\mathrm{H}$.

2008 Crisis and Chronicity: Anthropological Perspectives on Continuous Conflict and Decline, „Ethnos” nr 73 (1), s. 5-24. 